\title{
Measuring Severity of Downtime Influence Factors to Naval Ship Operational Availability: A Delphi Study
}

\author{
Al-Shafiq Bin Abdul Wahid ${ }^{1 *}$, Mohd Zamani Bin Ahmad², Sunarsih ${ }^{3}$, Mohd Najib Bin Abdul Ghani Yolhamid ${ }^{4}$, \\ Mohamad Abu Ubaidah Amir Abu Zarim ${ }^{5}$, Aisha Binti Abdullah ${ }^{6}$, Nur Hanani Bt Ahmad Azlan ${ }^{7}$ \\ 1,3,7 Faculty Of Mechanical Engineering, Universiti Teknologi Malaysia [UTM], 81310 Skudai, MALAYSIA \\ ${ }^{2}$ Institut Sultan Iskandar, UTM Skudai, 81310, MALAYSIA \\ ${ }^{4,5}$ Faculty Of Science And Defence Technology, Universiti Pertahanan Nasional Malaysia, Kem Sungai Besi, 57100, MALAYSIA \\ ${ }^{6}$ Enigma Technical Solutions Sdn Bhd, Business Centre, Desa Villas, Sec 10 Wangsamaju, 53300 Kuala Lumpur, MALAYSIA \\ *Corresponding Author E-Mail: Al_Shafiq@Hotmail.Com
}

\begin{abstract}
Rapid development of shipbuilding and ship repair industry in recent years has been increasingly transforming the way organizations apply the long term strategic thinking of "cradle to grave" maintenance approach in order to maximize their growth in a dynamic marine industry. With increased ship complexity, size and revolutionary design, organizations strive to balance ideal maintenance philosophies against on-going efforts of cost reduction whilst maintaining high availability of vessels. Despite aspiration and efforts to improve the ship availability, the Royal Malaysian Navy [RMN] vessels which are currently maintained under the In Service Support [ISS] Contracts are hardly tackling the human and equipment related aspects due to limited knowledge and available data on ship Downtime Influence Factors [DIFs]. The current research carried out an explorative study across various engineering disciplines to generate RMN ship maintenance DIFs and their severity measures via a 3-Stage Modified Delphi approach. 30 Experts experienced in daily implementation of naval ship maintenance contracts were involved. In the first stage, Focus Group Discussions [FGDs] amongst Experts were conducted to produce the DIFs, followed by questionnaire distribution to measure the severity of the DIFs in the second stage. In the third stage, the Severe DIFs were confirmed and ranked based on a Risk Assessment method. The study revealed 50 DIFs to RMN ship availability and deduced the top 15 Severe DIFs pinpointing the key problem areas to prioritize efforts in improving RMN ship availability.
\end{abstract}

Keywords: Naval vessels; navy ship maintenance; operational availability; Downtime Influence Factors [DIFs]; Delphi method.

\section{Introduction}

In contrast to merchant vessels, navy ships which naturally possess different functions, complex design characteristics [1] and concept of operations, are equipped with a vastly different range of equipment and systems onboard to suit its battle and combat management capabilities. A modern naval vessel or warship/ submarine would consist of in excess of 100 integrated systems that are linked structurally, mechanically, electrically, hydraulically, pneumatically and electronically [2]; thus warships/submarines may be viewed as a system of systems [3]. All of these systems need power and cooling, and many need to communicate with each other in order to achieve full operational capability [2]. Consequently, the naval ship operational availability turns into a complex problem [4]. Improving any asset's operational availability undoubtedly further complicates the problem due to a long list of interconnected contributing factors [5], where ambiguities and uncertainties involving human and equipment factors appear with unclear significance and unknown weightage.

Following [6] and [7], availability is defined as the probability that the ship is available and capable of performing the intended function at any random point in time. Availability which is also commonly known as 'Uptime' can be formulated as one minus Downtime [8] or known as Unavailability, with the resulting mathemati- cally implication that the more the unavailability or 'Downtime', the lesser the availability yielded. Ship operational availability is also described as the number of days the warships are available for operational tasking in a year [9].

To date, no literature attempted to consolidate human and equipment related factors in the ships study, which is probably due to complexity or absence of the 'combined factors' from other field of studies. The most recent and closest research to navy ships availability was conducted by [4] who in regards of Italian navy highlighted that navy ships operational availability requires a more innovative and comprehensive approach in design as well as support. It was emphasized that operational availability is the key process for design of warships supportability and support systems as well as measurement, improvement and optimization of the ships and support systems during In-Service phase. The InService phase of a naval vessel will typically constitute $70 \%$ of the vessel's through-life cost [3] over its life cycle, therefore it is a significant area of research for efforts in optimization.

As opposed to the current trend of 'availability-based contract' in UK [10] and Australia [11], implementation of the In Service Support [ISS] Contracts in Malaysia remains based on 'execution upon receipt of order only' philosophy or commonly known as per-order basis. Decision on the maintenance services, training and procurement of spares including scheduling of works rely on Royal Malaysian Navy [RMN] directives, resulting in contractors 
having limited chance in achieving targeted availability figures. As such, since the contract itself is not designed for optimization efforts, improvement efforts on increasing ship operational availability rests mostly with RMN as the customer. Despite continuous improvement efforts and the implementation of three separate In Service Support contracts on RMN ships, each over a period of three years, the RMN aspires to improve the operational availability these vessels. Due to limited research on Downtime Influence Factors [DIFs] on ships, improvement efforts could not be allocated precisely in tackling issues involving combined "human and equipment" aspects impacting ship availability. Therefore, the purpose of this study is to generate RMN ship maintenance DIFs and their severity measures via eliciting expert opinions.

Other researchers have similarly used expert opinions to study maintenance downtime distribution which reflects availability of systems [12]. The author argues that expert opinions are necessary due to the fact that in many cases, the historical data or equipment downtime are limited and in poor quality therefore making them inappropriate for use in modeling. The application of expert opinion has been found in various studies covering a wide spectrum of discipline such as chemical, nuclear, health, aerospace and banking industries [13]. Considering some highlights revealed by [14] where Delphi method is best suited for researches of an institution backed with no previous history or a very complex phenomenon truly requires experts, the current research employed 3-Stage Mixed Method Modified Delphi approach to generate and measure the severity of DIFs to RMN ships operational availability.

\section{Literature review}

\subsection{Navy Ship Availability}

In general, there have been several previous studies on availability of equipment and systems from various disciplines, most of which were done on a component or equipment basis. In a way that most of the studies were carried out similar to the "factorization method' [15]; divide problems, tasks and functions into sub problems, subtasks and sub functions and solve individually. Mostly, past researchers focused on a selected area of study only such as spares assessment and conclude the study by creating a link to the end but refrain from consolidating all solutions for a complete solution which is absolutely the most difficult objective while implying that any proven improvement would result in an obvious improvement to the ship availability indirectly. Whilst the solutions for the sub problems, subtasks and sub functions have to be combined to arrive at one common solution once they achieved, [15] reiterated that selection of the most technically and economically favourable combinations of principles from a large field of theoretically possible combinations is also a problem.

However, examining availability of a complex asset made up of several systems and equipment which run in series and parallel is far more complicated than studying on single component or equipment basis. For complex systems, arriving at a list of critical component may become more cumbersome due to potential timevarying load profile or internal components redundancies [16]. As a result, very limited studies on availability of complex assets or sophisticated systems have been conducted. Nevertheless, several researchers have studied a selected portion of the system [17] availability prediction [18], conceptual and optimization models [4, $19,20]$, improvement of availability by improving scheduling [4, 21] and avoiding scheduling conflicts [22-24], promotion of a "design for availability" approach $[25,26]$ and even provision of various methods in calculating the availabilities [4].

Many navies around the globe face the same challenges of achieving high asset availability, albeit the situation is aggravated due to the complex nature of warships [27]. Modern navies such as Italian and French Navy [4], United States Navy [28], Royal Malaysian Navy [29] and Korean Navy [30], have specified targeted operational availability targets, but it is interesting to note that availability is still a problem even in the United States Navy [28] even lately. Any effort resulting in an increase of ship operational

availability is commendable [31]. A Ship is a reliable performer when it has a lower annual downtime [32] therefore availability of the naval warship is a mark of its reliability. In fact, one of the measure of reliability of repairable systems is availability [33]. To present an indicative value of the losses due to downtime, [32] described that for a ship valued at $\$ 500 \mathrm{M}$ and a 30 year target service life, the navy loses approximately $\$ 50 \mathrm{~K} /$ day if the ship is not able to operate.

The most recent and interesting study of naval ship availability was performed by [4] entitled Operational Availability [Ao] of Warships - A complex problem from concept to in service phase. The author attempted to initiate more studies on naval ship availability by introducing to the world that warships are complex and availability studies on warships would require encapsulation of all factors from concept to In-Service phase. It was highlighted that there is a need of a new design approach based on Operational Availability [Ao] of warships and associated support system in order to achieve best balance between Ao and Life Cycle Cost [LCC] along the whole operative life. Figure 1 displayed an example of Life Cycle Cost [LCC] Tree disclosed by the author.

Life Cycle cost

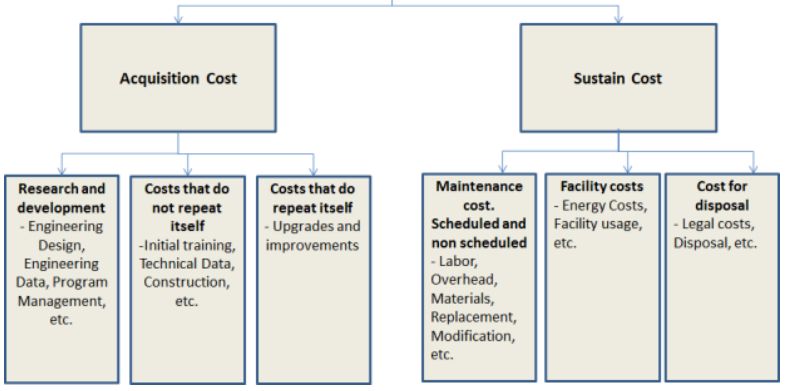

Fig. 1: The Life Cycle Cost [LCC] Tree [34]

Availability is also a measure of maintenance performance [35] Maintenance productivity aims at minimizing the maintenance cost dealing with the measurement of overall maintenance results, maintenance and maximizing the overall maintenance performance. Control of maintenance productivity [MP] ensures that the budgeted levels of maintenance efforts are being sustained and that required plant output is achieved [36]. Maintenance productivity deals with both maintenance effectiveness and efficiency [35], therefore availability is also closely related to both. The sole objective of the maintainability engineer is to reduce downtime [37], therefore to increase uptime or maximizing availability.

Due to issues of achieving high availability targets as expected by some customers, nowadays providers of complex engineered equipment are often encouraged to offer outcome or availabilitybased contracts or performance-based contract [PBC], where the provider guarantees the uptime and availability of the product [16, $38-40]$. This is to avoid or reduce the risks as faced by customers, such as in the process industry, whereby machine downtime in the shop floor is one of the main issues for maintenance productivity[35]. Maintenance activities are mostly non repetitive in nature, resulting in all maintenance personnel and managers facing new problems with each breakdown or downtime of plants or systems. Due to the conflicting multi-objectives issues, multiskill levels are needed [35] and retention of these special skills is also a common problem in maintenance [5, 11, 41-43].

\section{Methodology}

\subsection{The Delphi Study}

It is well agreed among researchers that Delphi method is preferred as a research instrument for incomplete knowledge about a problem or phenomenon [44-47] or in the case of limited experts in the field are available [44, 48]. [49] emphasized that the method is appropriate for researching complex issues where larger scale 
quantitative hard data fail to unearth richness in tacit knowledge to help the research understand subtle expert opinion. The scientific methodology provided by the Delphi is well-suited to issues that require the insights of subject matter experts

Whilst Delphi method is generally used with the aim of obtaining the most reliable group opinion [45], it is also useful for structuring a group communication process so that the process is effective in allowing a group of individuals, as a whole, to deal with the complex problem [50]. The method works especially well when the goal is to improve the understanding of problems, opportunities, solutions or to develop forecasts [44]. It is continuing to be a much used tool in the search for answers to normative questions [51] such as policy making [45].

With wide areas of implementation, the process of Delphi is normally the same [52]. Theoretically, the process can be continuously iterated until the consensus achieved [53]. However, while [54] suggested that a 2 or 3 iterations or stages, [55-57] and [58] pointed out that 3 iterations are often sufficient to collect needed information and reach a consensus in most cases. Further, [59] added that the responses on the final iteration usually show less spread in comparison to spreads in earlier iterations and median values are commonly taken as the best estimates for the issues.

On the implementation and enhancement of the Delphi method, various studies provided further details. Exclusively, [60] presented a framework for conducting the necessary Delphi research and how to enhance the usage of the Method including improving expert recruitment via snowballing and other methods of retention over Delphi rounds. Specifically, [61] recommended guidance and advice on sampling size for qualitative interviews based on a set of succinct "expert voice" contributions stating that saturation is central to qualitative sampling depending on the methodological and epistemological perspective. Meanwhile, [62] advised sample pool sizes and a mean of 30 though later confirmed that the best answer is simply to gather data until empirical saturation has reached since some qualitative researchers argued that as little as one expert opinion can add value to the area of research.

Among various issues based on cost, time and resources available considered in preferring the Delphi approach are outlined as follows:

i. Identification of factors affecting the downtime and therefore naval ships availability have not been itemized previously due to the complexity while identification of the most critical factors requires a Risk Analysis

ii. Limitation of current literatures relevant to availability of naval vessels encouraged the need for rich data collection hence allows the understanding of the stakeholder's experiences as well as requirements

iii. Requirement in addressing the presence of 'objective' and 'subjective' data as it spans across equipment/system and human related issues

iv. Limitation in the number of people who have access to ISS contract, knowledgeable and experienced in dealing directly with the implementation of ISS in Malaysia

v. Requirement on end result presentation as an availabilityoriented contract management model

vi. Various roles of participants/experts, nature of expertise, expert recruitment and retention over during the study

\subsection{Mixed Method Modified Delphi Approach}

The main component of the current research approach is the Delphi method. To strengthen the study, other methods are integrated appropriately at various stages of the Delphi study including Focus Group Discussion [FGD] and qualitative Risk Analysis method. The FGD served as initial expert validation of the DIFs identified via literature study, followed by two rounds of Delphi to re confirm the DIFs impact on ship availability and the severity of these DIFs. Figure 2 contains a diagrammatic representation of the method of identifying key variables.



Fig. 2: Method of Identifying Key Variables

\subsection{Identification of Research Variable}

Identification of the current research variables commenced from a detailed literature review concerning down time elements that affect the availability of naval vessels and downtime of equipment and systems from various fields of research. All pertinent information relevant to the scope of the current ISS Contract and other data from various stakeholders relevant to the study were gathered as well. A generic list of variables namely Downtime Influence Factors [DIFs] comprised of close to 100 variables were compiled and pooled in groups as the initial reference and basis of the study.

\subsection{Stage 1 - Focus Group Discussion}

Addressing the first stage of the Modified Delphi approach, a Focus Group Discussion [FGD] by Expert group was designed to confirm and screen the identified variables into relevant terms with more manageable numbers. Consolidations of different interpretations, cross-referring of various definitions as well as pooling similar variables into agreed categories were carefully executed during the session. 30 Expert members who were working directly on ISS Contract and other relevant organizations with adequate working experience and/ or knowledge in the ship maintenance area from contractor and the customer's organizations were selected to populate the variables based on their knowledge and experience. Table 1 and Table 2 listed the Expert members' details based on years of working experience and job positions/designations.

Table 1: Working experience of the Expert members

\begin{tabular}{|c|c|}
\hline Years & Percentage \\
\hline $0-5$ & $5 \%$ \\
\hline $6-10$ & $30 \%$ \\
\hline $11-20$ & $30 \%$ \\
\hline$>20$ & $35 \%$ \\
\hline
\end{tabular}

Table2: Job position/designation of the Expert members

\begin{tabular}{|l|c|}
\hline \multicolumn{1}{|c|}{ Designation } & Number \\
\hline Technical Executive & 6 \\
\hline Senior Technical Executive & 9 \\
\hline Supervisor & 1 \\
\hline Senior Supervisor & 2 \\
\hline Assistant Manager & 1 \\
\hline Manager & 3 \\
\hline Project Manager & 1 \\
\hline Head of Division & 3 \\
\hline Commanding Officer Navy Ships & 3 \\
\hline Senior Navy Engineer and Contract Manager & 1 \\
\hline Total & $\mathbf{3 0}$ \\
\hline
\end{tabular}

\subsection{Stage 2 - Delphi Round 1}

The next stage was the development of questionnaire for the usage in the Mixed Method Modified Delphi study employed by the current research. The questionnaire is constructed in structured questions which consisted of closed, dichotomous questions and Likert Scales. The questions which contained the 50 DIFs pro- 
duced by the FGD were brought forward to the next stage for further identification by the Expert group.

Taking advantage of the 50 DIFs identified in the FGD, each Expert member was asked to select the DIFs that have impact on ship availability via Risk Assessment method. Qualitatively, risk is proportional to the expected losses that can be induced by a certain accident and to the likelihood of an occurrence. Greater loss and greater likelihood result in an increased overall risk [63]. In engineering, the definition of risk is:

\section{RISK $=$ [Probability of Incident/Accident $] \times$ [Losses per Incident/Accident] [63]}

According to [63], the probability and impact matrix illustrates a risk rating assignment for individual risk factors. It shows the combination of impact and probability that in turn yields a risk rank or risk priority. Risk ranking is based on a matrix whose axes are the ranks of consequences and probabilities [63]. The likelihood of occurrence and consequences of scenarios as the result of their pairing is referred to as a Risk Assessment Matrix. Typical Risk Assessment Matrices vary with organizations, however [63] concludes that the most common type of matrices contain $3 \times 3$, $4 \times 4,5 \times 5,5 \times 4$ and $6 \times 4$ likelihood and consequences categorizations.

The NASA had used Risk Assessment Matrices to avoid the problem of managers treating the values of probability and risk as absolute judgments, whilst the US Department of Defense offers the use of risk assessment matrices as a tool to prioritize risk as cited in [64]. Based on [64], both the levels of occurrence and consequences may be based on expert-opinion elicitation.

The best suited Risk Assessment Matrix for the study was as a 5x5 Matrix, with a five points Likert Scale on the impact of the DIFs onto the ship availability for the ISS Contract and five degrees of DIFs probability occur throughout the contract duration employed for the rating as summarized in Table 3 are inquired for each DIF selected.

Table 3: Rating of DIFs severity

\begin{tabular}{|c|c|c|}
\hline Rating & Likert Scale of DIF Impact & $\begin{array}{c}\text { Degree of Probability of } \\
\text { DIF occurrence }\end{array}$ \\
\hline 5 & Extreme & Almost Certain \\
\hline 4 & High & Likely \\
\hline 3 & Medium & Possible \\
\hline 2 & Low & Unlikely \\
\hline 1 & Negligible & Rare \\
\hline
\end{tabular}

A risk analysis is executed to ascertain the severity of each DIF using a cut-off point which is defined as product of the impact scale and its degree of occurrence. Based on the given rating, a $4 \times 4$ cut-off point is employed in defining the severity of the DIFs. Hence, a DIF has to totally value at least 16 or possesses "High" impact and "Likely" probability of occurrence to be considered as important by labeled as "Severe" and remain to be evaluated in later stages. Consequently, any results below 16 in total or combinations of "Medium" or lower impact and "Possible" or lower occurrence were considered as "Not Severe" and taken out from further evaluation. Quantitative Analysis of the standard statistical software tool SPSS was employed to summarize and analyze the collected data and results are validated in subsequent stages.

\subsection{Stage 2 - Delphi Round 2}

In Delphi Round 2, Expert members were required to reassess the DIF ratings in the light of the consolidated results previously obtained. New questionnaires similar to previous ones were issued for feedback. The subsequent processes of computing DIFs severity and performing risk analysis are similar to Stage 2 - Delphi Round 1.

Further computation to compare results from Delphi Round 2 and previous results from Delphi Round 1 was performed by exploiting a coefficient of variation [CV]. Parametric statistical methods such as the CV and F-test have been used in Delphi studies with samples below 50 as stated in [65] . The CV which defines ratio of standard deviation $[\mathrm{SD}]$ of a competency area to its corresponding means $[\mathrm{AVG}]$ among the Expert members was formulated as:

$C V=\frac{S D}{A V G}$

Accordingly, an absolute difference was calculated by subtracting the $\mathrm{CV}$ of the current and previous stage. A small $\mathrm{CV}$ value would indicate that the data scatter or data variation compared to the mean is small and vice versa.

\section{Results and findings}

\subsection{Results Stage 1 - FGD}

50 groups of DIFs that impact ship availability was agreed by Expert members via FGD were generated as tabulated in Table 4.

Table 4: The 50 groups of DIFs agreed by expert group via FGD

\begin{tabular}{|c|c|c|c|}
\hline No & $\begin{array}{l}\text { DIFs for Ship Opera- } \\
\text { tional Availability }\end{array}$ & No & $\begin{array}{c}\text { DIFs for Ship Operational } \\
\text { Availability }\end{array}$ \\
\hline 1 & $\begin{array}{l}\text { Equipment and Systems - } \\
\text { Hull and Design }\end{array}$ & \multirow[t]{2}{*}{28} & \multirow[t]{2}{*}{$\begin{array}{l}\text { Morale \& Attitude of Contrac- } \\
\text { tor involved in Maintenance }\end{array}$} \\
\hline 2 & $\begin{array}{l}\text { Equipment and Systems - } \\
\text { Main Propulsion }\end{array}$ & & \\
\hline 3 & $\begin{array}{l}\text { Equipment and Systems - } \\
\text { Electrical }\end{array}$ & \multirow[t]{2}{*}{29} & \multirow{2}{*}{$\begin{array}{l}\text { Efficiency of Processes, Proce- } \\
\text { dures and reporting structure } \\
\text { include Finance }\end{array}$} \\
\hline \multirow[t]{2}{*}{4} & \multirow{2}{*}{$\begin{array}{l}\text { Equipment and Systems - } \\
\text { Weapon Systems includ- } \\
\text { ing guns and missiles }\end{array}$} & & \\
\hline & & 30 & $\begin{array}{l}\text { perational/sailing } \\
\text { le }\end{array}$ \\
\hline 5 & $\begin{array}{l}\text { Equipment and Systems - } \\
\text { Auxiliaries }\end{array}$ & 31 & $\begin{array}{l}\text { Non-Commonality of Equip- } \\
\text { ment issues }\end{array}$ \\
\hline 6 & and Systems - & 32 & Non Redundancy of Equipment \\
\hline \multirow[t]{2}{*}{7} & \multirow{2}{*}{$\begin{array}{l}\text { Maintenance Policy - } \\
\text { Priority on Type of } \\
\text { Maintenance }\end{array}$} & 33 & $\begin{array}{l}\text { High Turnover of maintenance } \\
\text { supervisors. }\end{array}$ \\
\hline & & 34 & High Turnover of maintainers \\
\hline \multirow[t]{3}{*}{8} & \multirow{3}{*}{$\begin{array}{l}\text { Awareness of Importance } \\
\text { of Maintenance / Attitude } \\
\text { - including hiding prob- } \\
\text { lems from becoming } \\
\text { official. }\end{array}$} & 35 & Diff \\
\hline & & 36 & Sta \\
\hline & & 37 & $\mathrm{Ca}$ \\
\hline 9 & $\begin{array}{l}\text { Maintenance Budget } \\
\text { Allocation }\end{array}$ & \multirow[t]{2}{*}{38} & \multirow{2}{*}{$\begin{array}{l}\text { Government Requirements and } \\
\text { Policies [i.e. EEP }{ }^{* 2} \text {, Offset } \\
\text { etc.], }\end{array}$} \\
\hline 10 & Info & & \\
\hline 11 & Prev & 39 & $\begin{array}{l}\text { Variation Order and Contract } \\
\text { Change }\end{array}$ \\
\hline 12 & $\mathrm{C}$ & 40 & of Equipment [Aging] \\
\hline 13 & Prec & 41 & For \\
\hline 14 & $\begin{array}{l}\text { Emer } \\
\text { Dock }\end{array}$ & 42 & $\mathrm{~A}$ \\
\hline 15 & echnology / & 43 & $\begin{array}{l}\text { Extraordinary Price Escalations } \\
\text { [Spares, Consumables, Equip- } \\
\text { ment] }\end{array}$ \\
\hline 16 & Sche & 44 & $\begin{array}{l}\text { Pilferage, Theft \& Fraud \& } \\
\text { Cheat }\end{array}$ \\
\hline 17 & $\begin{array}{l}\text { Maintena } \\
\text { Tools, Te }\end{array}$ & 45 & $\begin{array}{l}\text { OLM, ILM, DLM }{ }^{* 3} \text { - Overlap } \\
\text { of maintenance duties [contrac- } \\
\text { tual] and impact if not per- } \\
\text { formed }\end{array}$ \\
\hline 18 & Availa & \multirow[t]{2}{*}{46} & \multirow{2}{*}{$\begin{array}{l}\text { Contract Management across a } \\
\text { wide range of stakeholders with } \\
\text { conflicting interests }\end{array}$} \\
\hline 19 & Spares A & & \\
\hline 20 & Uos & \multirow[t]{3}{*}{47} & \multirow{3}{*}{$\begin{array}{l}\text { Impact of Parallel Contracts to } \\
\text { Schedule, Genuinity of Spares, } \\
\text { Professionalism of Repair } \\
\text { Team etc. }\end{array}$} \\
\hline 21 & $\begin{array}{l}\text { Design and Design } \\
\text { Change Issues }\end{array}$ & & \\
\hline \multirow[t]{2}{*}{22} & \multirow{2}{*}{$\begin{array}{l}\text { Knowledge Management } \\
\text { incl Training, Knowledge } \\
\text { and Skills }\end{array}$} & & \\
\hline & & \multirow[t]{2}{*}{48} & \multirow{2}{*}{$\begin{array}{l}\text { Supporting of the Vessel } \\
\text { outside of home ports [e.g. } \\
\text { issue on mob, availability of } \\
\text { materials etc.] }\end{array}$} \\
\hline 23 & $\begin{array}{l}\text { Availability of } \mathrm{OEM}^{* 1} \\
\text { Expert Support }\end{array}$ & & \\
\hline 24 & $\begin{array}{l}\text { Availability of Local } \\
\text { vendor support }\end{array}$ & \multirow[t]{2}{*}{49} & \multirow{2}{*}{$\begin{array}{l}\text { Exogenous factors [i.e. compa- } \\
\text { ny profit margin, administrative } \\
\text { costs, peripheral costs, support } \\
\text { cost] }\end{array}$} \\
\hline 25 & $\begin{array}{l}\text { Complexity and efficiency } \\
\text { of existing contract }\end{array}$ & & \\
\hline
\end{tabular}




\begin{tabular}{|c|l|l|l|}
\hline 26 & $\begin{array}{l}\text { Capability of Customer } \\
\text { performing Maintenance }\end{array}$ & 50 & $\begin{array}{l}\text { Exogenous factors - Contract } \\
\text { Concept [Total Maintenance } \\
\text { Package against segregated } \\
\text { orders without interrelation- } \\
\text { ships] and based on recommen- } \\
\text { dations }\end{array}$ \\
\hline
\end{tabular}

Abbreviations: ${ }^{* 1}$ OEM: Original Equipment Manufacturer, ${ }^{* 2}$ EEP Economic Enhancement Programme, ${ }^{* 3}$ OLM [Operational Level Maintenance], ILM [Intermediate Level Maintenance], DLM [Depot Level Maintenance] [29]

While the FGD served as expert validation of the generic DIFs identified by literature study, no further consensus concerning the 50 agreed DIFs was yielded. The $1^{\text {st }}$ Stage of Delphi was therefore designed to build the consensus among the 30 Expert members regarding the importance of each DIF towards the ship availability.

\subsection{Results Stage 2 - Delphi Round 1}

Consensus among the expert group members regarding the importance of each of the 50 DIF was achieved. Based on the Risk Analysis, a DIF with a total value or median of 16 was defined as "Severe" and considered as important. Table 5 displayed the Severe DIFs ranking from most severe [Rank 1] to least severe [Rank 15].

\begin{tabular}{|c|c|c|c|c|c|}
\hline Severe DIF & Count & Mean & Median & Mode & Rank \\
\hline $\begin{array}{l}\text { Corrective } \\
\text { Maintenance }\end{array}$ & 30 & 24.20 & 25.00 & 25.00 & 1 \\
\hline $\begin{array}{l}\text { Spares Availabil- } \\
\text { ity }\end{array}$ & 30 & 22.90 & 25.00 & 25.00 & 2 \\
\hline $\begin{array}{l}\text { Impact of Paral- } \\
\text { lel Contracts to } \\
\text { Schedule, Genu- } \\
\text { inity of Spares, } \\
\text { Professionalism } \\
\text { of Repair Team } \\
\text { etc. }\end{array}$ & 30 & 21.70 & 25.00 & 25.00 & 3 \\
\hline $\begin{array}{l}\text { Cashflow Short- } \\
\text { ages }\end{array}$ & 30 & 21.57 & 25.00 & 25.00 & 4 \\
\hline $\begin{array}{l}\text { Knowledge } \\
\text { Management } \\
\text { incl. Training, } \\
\text { Knowledge, } \\
\text { Skills and } \\
\text { System }\end{array}$ & 30 & 19.63 & 20.00 & 20.00 & 5 \\
\hline $\begin{array}{l}\text { Equipment and } \\
\text { Systems - Main } \\
\text { Propulsion }\end{array}$ & 30 & 18.83 & 20.00 & 20.00 & 6 \\
\hline $\begin{array}{l}\text { Maintenance } \\
\text { Policy - Priority } \\
\text { on Type of } \\
\text { Maintenance }\end{array}$ & 30 & 18.00 & 20.00 & 20.00 & 7 \\
\hline $\begin{array}{l}\text { Availability of } \\
\text { OEM Expert } \\
\text { Support } \\
\end{array}$ & 30 & 17.43 & 16.00 & 16.00 & 8 \\
\hline $\begin{array}{l}\text { Maintenance } \\
\text { Budget } \\
\text { Allocation }\end{array}$ & 30 & 17.23 & 16.00 & 16.00 & 9 \\
\hline $\begin{array}{l}\text { Awareness of } \\
\text { Importance of } \\
\text { Maintenance / } \\
\text { Attitude - } \\
\text { including hiding } \\
\text { problems from } \\
\text { becoming } \\
\text { official. }\end{array}$ & 30 & 16.97 & 16.00 & 16.00 & 10 \\
\hline $\begin{array}{l}\text { Availability of } \\
\text { Facilities }\end{array}$ & 30 & 16.70 & 16.00 & 16.00 & 11 \\
\hline $\begin{array}{l}\text { Availability of } \\
\text { Local vendor } \\
\text { support }\end{array}$ & 30 & 16.70 & 16.00 & 16.00 & 12 \\
\hline $\begin{array}{l}\text { Complexity and } \\
\text { efficiency of } \\
\text { existing contract }\end{array}$ & 30 & 16.20 & 16.00 & 16.00 & 13 \\
\hline $\begin{array}{l}\text { Scheduling } \\
\text { Issues }\end{array}$ & 30 & 16.03 & 16.00 & 16.00 & 14 \\
\hline
\end{tabular}

\begin{tabular}{|l|l|l|l|l|l|}
\hline $\begin{array}{l}\text { Equipment and } \\
\begin{array}{l}\text { Systems - } \\
\text { Auxiliaries }\end{array}\end{array}$ & 30 & 15.33 & 16.00 & 16.00 & 15 \\
\hline
\end{tabular}

\subsection{Results Stage 3 - Delphi Round 2}

After re-assessment of the DIFs severity in Delphi Round 2, the agreement level among the Expert members had improved based on the $\mathrm{CV}$ values. Table 6 summarizes the absolute difference between results of Delphi Round 1 and Round 2.

Table 6: Absolute difference of Delphi Round 1 and Round 2

\begin{tabular}{|c|c|c|c|}
\hline \multirow{2}{*}{ Severe DIFs } & \multicolumn{2}{|c|}{$\mathbf{C V}$} & \multirow{2}{*}{$\begin{array}{l}\text { CV R1 } \\
\text { CV R2 }\end{array}$} \\
\hline & R1 & $\mathbf{R 2}$ & \\
\hline Corrective Maintenance & 0.09 & 0.06 & 0.03 \\
\hline Spares Availability & 0.19 & 0.16 & 0.03 \\
\hline $\begin{array}{l}\text { Impact of Parallel Contracts to Schedule, } \\
\text { Genuinity of Spares, Professionalism of } \\
\text { Repair Team etc. }\end{array}$ & 0.23 & 0.17 & 0.06 \\
\hline Cashflow Shortages & 0.24 & 0.15 & 0.09 \\
\hline $\begin{array}{l}\text { Knowledge Management incl. Training, } \\
\text { Knowledge, Skills and System }\end{array}$ & 0.09 & 0.08 & 0.01 \\
\hline Equipment and Systems - Main Propulsion & 0.20 & 0.06 & 0.14 \\
\hline $\begin{array}{l}\text { Maintenance Policy - Priority on Type of } \\
\text { Maintenance }\end{array}$ & 0.22 & 0.15 & 0.07 \\
\hline Availability of OEM Expert Support & 0.17 & 0.17 & - \\
\hline Maintenance Budget Allocation & 0.13 & 0.13 & - \\
\hline $\begin{array}{l}\text { Awareness of Importance of Maintenance / } \\
\text { Attitude - including hiding problems from } \\
\text { becoming official. }\end{array}$ & 0.14 & 0.13 & 0.01 \\
\hline Availability of Facilities & 0.15 & 0.14 & 0.01 \\
\hline Availability of Local vendor support & 0.21 & 0.20 & 0.01 \\
\hline $\begin{array}{l}\text { Complexity and efficiency of existing } \\
\text { contract }\end{array}$ & 0.19 & 0.13 & 0.06 \\
\hline Scheduling Issues & 0.18 & 0.12 & 0.06 \\
\hline Equipment and Systems - Auxiliaries & 0.27 & 0.19 & 0.08 \\
\hline
\end{tabular}
In summary,

- Mean of [CV R1-CV R2] $=0.04$

- Median of [CV R1 - CV R2] =0.03

- Max of [CV R1 - CV R2] = 0.14

- Min of [CV R1 - CV R2] $=0.00$

Whilst [66] marked that values of [CV R1 - CV R2] below 0.2 are considered as minor, [65] added that henceforth the stopping rule is applied for the Delphi study. Noting such highlights, it is deduced that stability of each Severe DIF was reached at Round 2 and no further Delphi rounds were required.

However, whilst the consensus amongst Experts had increased the ranking of the Severe DIFs remains unchanged as displayed in Table 7 .

Table 7: Validation result of Severe DIFs via Delphi Round 2

\begin{tabular}{|c|c|c|c|c|c|}
\hline Severe DIF & Count & Mean & Median & Mode & Rank \\
\hline $\begin{array}{l}\text { Corrective Mainte- } \\
\text { nance }\end{array}$ & 30 & 24.50 & 25.00 & 25.00 & 1 \\
\hline Spares Availability & 30 & 23.40 & 25.00 & 25.00 & 2 \\
\hline $\begin{array}{l}\text { Impact of Parallel } \\
\text { Contracts to } \\
\text { Schedule, Genuini- } \\
\text { ty of Spares, Pro- } \\
\text { fessionalism of } \\
\text { Repair Team etc. }\end{array}$ & 30 & 22.80 & 25.00 & 25.00 & 3 \\
\hline $\begin{array}{l}\text { Cashflow Shortag- } \\
\text { es }\end{array}$ & 30 & 22.63 & 25.00 & 25.00 & 4 \\
\hline $\begin{array}{l}\text { Knowledge } \\
\text { Management incl. } \\
\text { Training, } \\
\text { Knowledge, Skills } \\
\text { and System }\end{array}$ & 30 & 20.20 & 20.00 & 20.00 & 5 \\
\hline $\begin{array}{l}\text { Equipment and } \\
\text { Systems - Main } \\
\text { Propulsion }\end{array}$ & 30 & 20.03 & 20.00 & 20.00 & 6 \\
\hline $\begin{array}{l}\text { Maintenance } \\
\text { Policy - Priority on } \\
\text { Type of } \\
\text { Maintenance }\end{array}$ & 30 & 19.13 & 20.00 & 20.00 & 7 \\
\hline
\end{tabular}




\begin{tabular}{|l|c|c|c|c|c|}
\hline $\begin{array}{l}\text { Availability of } \\
\text { OEM Expert } \\
\text { Support }\end{array}$ & 30 & 17.43 & 16.00 & 16.00 & 8 \\
\hline $\begin{array}{l}\text { Maintenance } \\
\text { Budget Allocation }\end{array}$ & 30 & 17.37 & 16.00 & 16.00 & 9 \\
\hline $\begin{array}{l}\text { Awareness of } \\
\text { Importance of } \\
\begin{array}{l}\text { Maintenance / } \\
\text { Attitude - } \\
\text { including hiding } \\
\text { problems from } \\
\text { becoming official. }\end{array}\end{array}$ & 30 & 17.23 & 16.00 & 16.00 & 10 \\
\hline $\begin{array}{l}\text { Availability of } \\
\text { Facilities }\end{array}$ & 30 & 17.10 & 16.00 & 16.00 & 11 \\
\hline $\begin{array}{l}\text { Availability of } \\
\text { Local vendor } \\
\text { support }\end{array}$ & 30 & 17.00 & 16.00 & 16.00 & 12 \\
\hline $\begin{array}{l}\text { Complexity and } \\
\text { efficiency of } \\
\text { existing contract }\end{array}$ & 30 & 16.97 & 16.00 & 16.00 & 13 \\
\hline Scheduling Issues & 30 & 16.83 & 16.00 & 16.00 & 14 \\
\hline $\begin{array}{l}\text { Equipment and } \\
\text { Systems - } \\
\text { Auxiliaries }\end{array}$ & 30 & 16.33 & 16.00 & 16.00 & 15 \\
\hline
\end{tabular}

Figure 3 illustrates the rating of the Severe DIFs by Expert group members. The key observation is that whilst the vast majority of experts have assessed the Severe DIFs with a rating of 16 and above, there were a few outliners. The researcher requested the expert to provide justification for the rating. The key factor in assigning a significant different rating was due to having been exposed to a lesser extent to the DIF due to limited ISS contract experience and limited working experience.

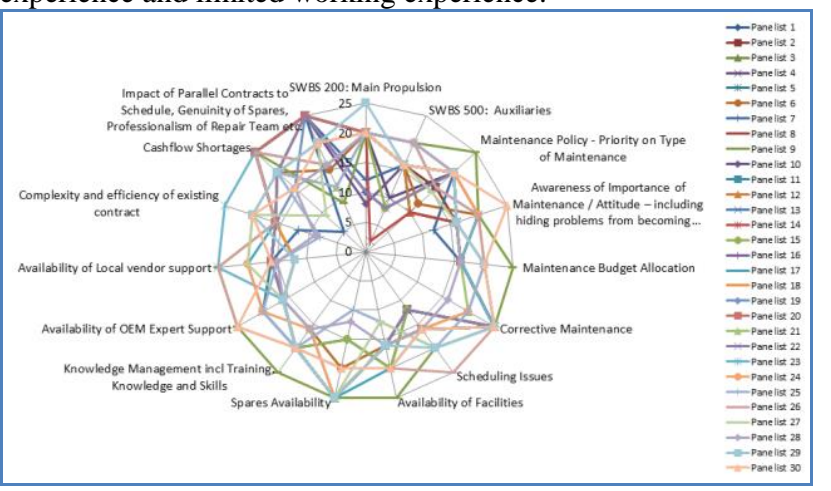

Fig. 3: Final Assessment of Severe DIFs

\section{Conclusion}

The current research has proven the reliability of Delphi method in tackling the complex problem of naval ship operational availability involving combined factors of human and equipment. Enhancing the factorization method mostly used in past researches which result in creation of individual solutions, the Mixed Method Modified Delphi study employed in the current research has led to generation of an integrated and more comprehensive solution in studying the factors affecting availability, holistically. Exploiting the enriched Delphi method, consensus amongst the experts has been reached and consolidation of DIFs in the naval ship domain has been attained.

This research is probably one of the most comprehensive study of its nature in consolidation of DIFs in the naval ship domain. The research pinpointed to 15 Severe DIFs as the key problem areas for prioritization of efforts in improving RMN ship availability. Furthermore, the acquired DIFs and Severe DIFs captured both human and equipment related issues which are commonly faced by all maintenance organizations facing continuous inter-related issues in improving their operational availability.

Equally important, the current research has set a fundamental basis of an availability-oriented contract management model as new knowledge towards improving naval ship operational availability.

\section{References}

[1] Al-Chalabi HS, Lundberg J, Wijaya A, Ghodrati B. Downtime analysis of drilling machines and suggestions for improvements Journal of Quality in Maintenance Engineering. 2014;20[4]:306-32.

[2] SIA. The Collins Class: Submarine Institute of Australia. Available from: http://www.submarineinstitute.com/submarines-inaustralia/the-Collins-Class.html.

[3] Ford G, McMahon C, Rowley C. Naval Surface Ship In-service Information Exploitation. In: Roy R, Tiwari A, Shaw A, Bell C, Phillips P, editors. Procedia CIRP, 2nd International Through-life Engineering Services Conference: Elsevier; 2013. p. 92-8.

[4] Dell'Isola A, Vendittelli A. Operational availability [Ao] of warships: A complex problem from concept to in service phase. 2015 IEEE Metrology for Aerospace [MetroAeroSpace]. 2015:2632.

[5] GAO. Factors Limiting The Availability Of F-15 Aircraft At The 1st Tactical Fighter Wing. US General Accounting Office [GAO]; 1982.

[6] Blanchard BS, Fabrycky WJ. Systems Engineering and Analysis. 3rd Edition ed: Prentice Hall; 1998.

[7] Inozu B. Reliability, Availability and Maintainability [RAM] Database of Ship Operations Cooperative Program. PN 1996 Research Project No. 95-18.

[8] Na H, Yi L, Wang Y-G, Liu J-j, Bo Z, Lv X-Z, editors. Research on the Mean Logistic Delay Time of the Development Phrass. Physics Procedia - International Conference on Medical Physics and Biomedical Engineering [ICMPBE2012]; 2012: Elsevier B.V.

[9] GAO. Navy Force Structure: Sustainable Plan and Comprehensive Assessment Needed to Mitigate Long-Term Risks to Ships Assigned to Overseas Homeports. US Government Accountability Office [GAO]; 2015.

[10] Tomkins C. Transforming Warship Support: Class Output Management. RUSI Defence Systems. 2012;15, No.2[Autumn/Winter 2012].

[11] Henry R, Bil C, editors. Sustainment Management in the Royal Australian Navy. Transdisciplinary Lifecycle Analysis of Systems Proceedings of the 22nd ISPE Inc International Conference on Concurrent Engineering; 2015 20-23 July: IOS Press.

[12] Hussin H, Hashim FM. Modeling of Maintenance Downtime Distribution using Expert Opinion. Journal of Applied Sciences. 2011;11[9]:1573-9.

[13] Goossens LHJ, Cooke RM, Halea AR, Rodić-Wiersma L. Fifteen years of expert judgement at TUDelft. Safety Science. 2008;46[2]:234-44.

[14] Franklin KK, Hart JK. Idea Generation and Exploration: Benefits and Limitations of the Policy Delphi Research Method. Innovative Higher Education 2007;31[4]:237-46.

[15] Pahl G, Beitz W, Feldhusen J, Grote K-H. Engineering Design: A systematic approach. edition r, editor: Springer; 2007.

[16] Reimann J, Kacprzynski G, Cabral D, Marini R. Using Condition Based Maintenance to Improve the Profitability of Performance Based Logistic Contracts Annual Conference of the Prognostics and Health Management Society2009.

[17] Rosenberger M, Pointner F. High availability: definition, influencing factors and solutions. Signal + Draht 2015:32-7.

[18] Bhagwan R, Tati K, Cheng Y-C, Voelker GM, editors. Total recall: system support for automated availability management. NSDI'04 Proceedings of the 1st conference on Symposium on Networked Systems Design and Implementation; 2004 March 29 - 31; San Francisco, California.

[19] Keating EG. Contracting for Weapon System Repair: An Examination of Alternative Approaches. RAND CORPORATION. 1996.

[20] Pan E, Liao W, Xi L. A single machine-based scheduling optimisation model integrated with preventive maintenance policy for maximizing the availabilty. International Journal of Industrial and Systems Engineering. 2012;10[4].

[21] GAO. Navy Air Launched Missiles-Increased Availability Through Improved Inspection and Maintenance Scheduling Practices. US Government Accountability Office [GAO]; 1981.

[22] Badiru D. Getting Things Done Through Project Management: iUniverse; 2009.

[23] Wilson R. A Comprehensive Guide to Project Management Schedule and Cost Control: Methods and Models for Managing the Project Lifecycle. 1st Edition ed: Pearson FT Press; 2014 April 19, 2014.

[24] Bradley SR, Hayter CS, Link AN. Models and Methods of University Technology Transfer. Greensboro: University of North Carolina; 2013.

[25] Jazouli T, Sandborn P. Using PHM to meet availability-based 
contracting requirements. IEEE Conference on Prognostics and Health Management; Montreal2011. p. 1-12.

[26] Jazouli T, Sandborn P. A Design for Availability Approach for Use with PHM. Annual Conference of the Prognostics and Health Management Society2010.

[27] Canada DoMS. LEADMARK: The Navy's Strategy for 2020 Ottawa, Ontario: Art Direction by DGPA Creative Services; 2001.

[28] Marais KB, Rivas J, Tetzloff IJ, Crossley WA. Modeling the impact of maintenance on naval fleet total ownership cost. Systems Conference [SysCon], 2013 IEEE International; Orlando, FL2013. p. 801-8.

[29] RMN. RMN Patrol Vessel - In-Service Support Contract. Royal Malaysian Navy [RMN]; 2011.

[30] Paik S. A Study on the Case Study and Evaluation Methodology of Operational Availability for a Naval Ship using OT\&E Data. Journal of the KIMST. 2014;17:471-8.

[31] Record C. Tribute to Admiral Frank "Skip" Bowman. U S Congress; 2004. p. 23469.

[32] Stambaugh K, Barry C. Naval Ship Structure Service Life Considerations. Naval Engineers Journal. 2014;126[3]:103-17.

[33] Peiravi A. Redundancy and Reliability of Air to Air Missile Fuze Electronics Journal of American Science. 2010;6[2]:147-54.

[34] Dell'Isola A, Vendittelli A. The Life Cycle Cost [LCC] Tree. Operational availability [Ao] of warships: A complex problem from concept to in service phase: IEEE Metrology for Aerospace [MetroAeroSpace]; 2015. p. The Life Cycle Cost [LCC] Tree.

[35] Parida A, Kumar U. Handbook of Maintenance Management and Engineering: Maintenance Productivity and Performance Measurement XXVII ed: Springer; 2009.

[36] Kelly A. Maintenance Organization and Systems: ButterworthHeinemann; 1997.

[37] Pecht M. Product Reliability, Maintainability, and Supportability Handbook. Second Edition ed: CRC Press; 2009.

[38] Neely A, Benedetinni O, Visnjic I. The Servitization of Manufacturing: Further Evidence. 18th European Operations Management Association Conference; July Cambridge2011.

[39] Jin T, Xiang Y, Cassady R, editors. Understanding operational availability in performance-based logistics and maintenance services. Reliability and Maintainability Symposium [RAMS], 2013 Proceedings - Annual; 2013 28-31 Jan. 2013; Orlando, FL, USA: IEEE.

[40] Dattaa PP, Rajkumar Royb. Cost modelling techniques for availability type service support contracts: A literature review and empirical study. CIRP Journal of Manufacturing Science and Technology. 2010;3[2]:142-57.

[41] Bateson JT. In-Circuit Testing: Springer Netherlands; 1985

[42] U.S. Congress OoTA. The Social Security Administration and Information Technology-Special Report. [Washington, DC: U.S. Government Printing Office, 1986 NTIS order \#PB87-136834.

[43] GAO. AVIATION WORKFORCE: Current and Future Availability of Aviation Engineering and Maintenance Professionals. U.S. Government Accountability Office [GAO]; 2014.

[44] Skulmoski GJ, Hartman FT, Krahn J. The Delphi Method for Graduate Research Journal of Information Technology Education. 2007;6.

[45] Adler M, Ziglio E. Gazing into the Oracle - The Delphi Method and its Application to Social Policy and Public Health: Jessica Kingsley Publishers; 1996.

[46] Czinkota MR, Ronkainen IA. International Business and Trade in the Next Decade: Report from a Delphi Study. Journal of International Business Studies. 1997;28[4]:827-44.

[47] Linstone HA, Turoff M. The Delphi Method: Techniques and Applications2002.

[48] Cuhls K. Delphi Method2002/2003:[95 p.].

[49] Grisham T. The Delphi technique: a method for testing complex and multifaceted topics. International Journal of Managing Projects in Business. 2009;2[1]:112-30.

[50] Márquez AC. The Maintenance Management Framework: Models and Methods for Complex Systems Maintenance: Springer; 2007.

[51] Rieger WG. Directions in Delphi developments: dissertations and their quality. Technological Forecasting and Social Change. 1986;29:195-204.

[52] Yousuf MI. Using Experts' Opinions Through Delphi Technique. Practical Assessment, Research \& Evaluation. 2007;12.

[53] Hsu C-C, Sandford BA. The Delphi Technique: Making Sense Of Consensus. Practical Assessment, Research \& Evaluation. 2007;12.

[54] Delbecq AL, Ven AHVD, Gustafson DH. Group Techniques for Program Planning: A Guide to Nominal Group and Delphi Processes. 1st edition ed: Green Briar Press; 1975.
[55] Cyphert FR, Gant WL. The Delphi technique: A case study. 1971;52:272-3

[56] Brooks KW. Delphi technique: expanding applications. North Central Association Quarterly. 1979;54:377-85.

[57] Ludwig B. Predicting the Future: Have you considered using the Delphi Methodology? Tools of the Trade 5TOT2. 1997;35, No.5.

[58] Custer RL, Scarcella JA, Stewart BR. The Modified Delphi Technique - A Rotational Modification. Journal of Career and Technical Education. 1999;15[2].

[59] Riggs WE. The Delphi Technique: An Experimental Evaluation. Technological Forecasting and Social Change. 1983;23:89-94.

[60] Rowe G, Wright G. The Delphi technique: Past, present, and future prospects - Introduction to the special issue. Technological Forecasting \& Social Change. 2011;78:1487-90.

[61] Baker SE, Edwards R. How many qualitative interviews is enough? Expert voices and early career reflections on sampling and cases in qualitative research 2012 .

[62] Adler PA, Adler P. The Tender Cut: Inside the Hidden World of Self-Injury 2nd edition ed: NYU Press; 2011 August 22.

[63] Ristic D. A tool for risk assessment Journal Safety Engineering. 2013;UDC 512.64:614.026.1,:121-7.

[64] Ayyub BM. Methods for Expert-Opinion Elicitation of Probabilties and Consequences for Corps Facilities. U.S. Army Corps of Engineers, Institute for Water Resources, 2000 December. Report No.: IWR Rport -00-R-10.

[65] Shah HA, Kalaian SA. Which Is the Best Parametric Statistical Method For Analyzing Delphi Data? Journal of Modern Applied Statistical Methods 2009;8[1]: Article 20.

[66] Dajani JS, Sincoff MZ, Talley WK. Stability and agreement criteria for the termination of Delphi studies. Technological Forecasting and Social Change. 1979;13:83-90 